${ }^{3}$ Brown GW. Experiences of discharged chronic schizophrenia patients in various types of living group. Milbank Memorial Fund Quarterly $1959 ; 37: 105-31$

${ }^{4}$ Brown GW, Monck EM, Carstairs GM, Wing JK. Influence of family life on the course of schizophrenic illness. Br F Prev Soc Med 1962; $16: 55-68$.

${ }^{5}$ Rutter M, Brown G. The reliability and validity of measures of family life and relationships in families containing a psychiatric patient. Social Psychiatry 1966;1:38-53.

${ }^{6}$ Brown GW, Birley JLT, Wing JK. Influence of family life on the course of schizophrenic disorders: a replication. Br $\mathcal{F}$ Psychiatry 1972;121 241-58.

7 Leff JP, Wing JK. Trial of maintenance therapy in schizophrenia. Br Med f 1971 ;iii :599-604.

8 Vaughn C, Leff JP. The measurement of expressed emotion in the families of psychiatric patients. Br $\mathcal{F}$ Soc Clin Psychol 1976;15:157-65.

- Vaughn CE, Leff JP. The influence of family life and social factors on the course of psychiatric illness. A comparison of schizophrenic and depressed neurotic patients. Br $\mathcal{F}$ Psychiatry 1976;129:125-37.

10 Tarrier N, Vaughn C, Leff JP, Lader MH. Bodily reactions to people and events in schizophrenia. Arch Gen Psychiatry 1979;36:311-5.

11 Venables PH, Wing JK. Level of arousal and the subclassification of schizophrenia. Arch Gen Psychiatry 1962;7:114-9.

12 Birley JLT, Brown GW. Crises and life changes preceding the onset or relapse of acute schizophrenia: clinical aspects. Br f Psychiatry 1970; $126: 327-33$

13 Leff J, Vaughn C. The interaction of life events and relatives' expressed emotion in schizophrenia and depressive neurosis. $\mathrm{Br} \mathcal{F}$ Psychiatry $1980 ; 136$ : 146-53.

\section{Special hospital transfers}

Special hospitals seem fated to be constantly in the news in Britain-usually because of some criticism. A report published in March, simultaneously as a Special Hospitals Research Report $^{1}$ and a paper in the British fournal of Psychiatry, ${ }^{2}$ resulting from work commissioned by the DHSS and carried out by Mrs S Dell of the Institute of Psychiatry in London, gave another view, highlighting some of the difficulties under which the hospitals work.

At the end of 1976 there were 2200 patients in the four establishments (Broadmoor, Rampton, Moss Side, and Park Lane) run directly by the DHSS as maximum security hospitals for the care of patients with "dangerous, violent, or criminal propensities." During the year $8 \%(161)$ of the patients had been approved for transfer. Mrs Dell found that this approval was a somewhat capricious process; the chances were lower for patients in hospitals where there was a high turnover among the consultants, presumably because a doctor needs time to get to know a patient well enough to form a view on his suitability for release. Clearly, too, different doctors had different views on suitability for release, so that a patient's chance of being recommended for transfer could depend less on him than on his doctor.

By the autumn of 1978 a quarter of the 161 patients whose transfer had been approved in 1976 were still waiting for admission to an NHS hospital. "Various reasons are given by the NHS hospitals [for the transfer delays] but it is often uncertain," says Mrs Dell, "how much they reflect reality." In many cases an ever-changing string of objections seemed to be an attempt to make acceptable the uncomfortable truth that the hospital did not want to take the patient, whom they feared as potentially difficult or even dangerous. Lack of room was the reason most commonly advanced for not taking patients-usually the mentally handicapped. The next most frequent reason related to the patient's character or characteristics. Third on the list came refusal by staff; in such cases the patients had usually not been visited at the special hospitals by the prospective consultant and his nurse. Overall, the research showed that the gravest difficulties were encountered not by mentally ill offenders but by handicapped civil patients with no criminal record at all.

The report suggests four ways in which the position may be improved. Firstly, proper services need to be provided for the mentally handicapped; secondly, the special hospitals need to ensure that NHS consultants see their prospective patients before coming to decisions about them; thirdly, more patients could be discharged directly to the community; and, fourthly, "there is a need for the DHSS at the appropriate level to come to grips with the issues involved."

Psychiatrists will be all too familiar with the problems outlined in this report, for every district in every part of Britain has one or two difficult patients who require long-term care and slow intensive rehabilitation, sometimes after time spent in a special hospital or a prison. Provision for such patients is extremely poor and-as the report hints-staff are often actively hostile towards this group of people. Nurses and other staff seem afraid of the consequences of caring for disturbed and possibly dangerous people. The current philosophy is for a steady move away from care in mental hospitals and mental handicap hospitals towards so-called community care. The recent Jay Report ${ }^{3}$ on the mentally handicapped is a good example of the advice being given along these lines. So far the only provision for "difficult" patients that has been proposed for a world without mental hospitals is the regional secure unit, which will supposedly keep them for short periods-say, 18 months. As the $B M Y$ has pointed out previously, ${ }^{5}$ experimental and pilot units need to be established so that policies can be formulated in the light of practical experience rather than untested, armchair theories.

${ }^{1}$ Dell S. The transfer of special hospital patients to National Health Service hospitals. Special Hospitals Research Report No 16. London: DHSS, 1980.

2 Dell S. Transfer of special hospital patients to the NHS. Br $\mathcal{F}$ Psychiatry $1980 ; 136: 222-34$.

${ }^{3}$ Report of the Committee of Enquiry into mental handicap nursing care. Cmnd 7468-1. London: HMSO, 1979.

4 Anonymous. Mentally disordered offenders. $B r$ Med F 1979;i:1-2.

5 Anonymous. NHS security beds. $\mathrm{Br} \mathrm{Med} \mathcal{F}$ 1979;i:1585-6.

\section{Mild asymptomatic hyperparathyroidism}

With the widespread use of multichannel analysers in hospitals, the serum calcium concentration is becoming increasingly available as a routine measurement. Predictably this has resulted in a dramatic increase in the incidence of detected hypercalcaemia, much of it mild and asymptomatic. In a recent study from the Mayo Clinic, ${ }^{1}$ Minnesota, the annual incidence of primary hyperparathyroidism detected by routine screening reached a peak rate of 188 cases per 100000 among women aged 60 and over. In the study as a whole nearly $80 \%$ of the patients had a mean serum calcium concentration below $2.75 \mathrm{mmol} / 1(11.0 \mathrm{mg} / 100 \mathrm{ml})$ and in half it was less than $2.6 \mathrm{mmol} / 1(10.4 \mathrm{mg} / 100 \mathrm{ml}$ ) (normal range $2.20-2.50 \mathrm{mmol} / \mathrm{l}$, $8 \cdot 8-10.0 \mathrm{mg} / 100 \mathrm{ml}$ ). The critical question is whether this degree of asymptomatic parathyroid overactivity is an indication for parathyroidectomy and, if not, what type of medical follow-up is required. Experience with hypertension has shown that the best approach to assessing the value of 
treatment is to look at outcome at definite levels of abnormality rather than try to identify "healthy" and "diseased" populations. In these circumstances "disease" starts at that level of abnormality where investigation and treatment begin to do more good than harm. ${ }^{2}$

For the patient with symptoms from "stones, bones, abdominal groans, or psychic moans" probably few would dissent from the recommendation of parathyroidectomy almost irrespective of the degree of hypercalcaemia, provided that he or she was not very old or unfit for surgery. At present, however, we do not have sufficient data to express numerically the risk of subsequent renal impairment, a reduction in bone mass, or major psychiatric symptoms as a consequence of untreated, mild, uncomplicated hyperparathyroidism.

The best data that we have came from the study of Purnell and his colleagues, ${ }^{3}$ who followed 147 patients with a serum calcium concentration under $2.75 \mathrm{mmol} / 1$ for five years. About $20 \%$ were lost to follow-up, an equal proportion had parathyroidectomy ( $3 \%$ because of deteriorating renal function), $4 \%$ died from unrelated conditions, and the rest remained well. Whether the proportion developing impairment of renal function is typical is not clear. While all patients had normal renal function at entry to the study an unspecified proportion also had "metabolically inactive stones." We are not told whether those with stones fared less well than those without. This may, however, become less of a problem in the future because hypercalcaemic patients who have been identified by screening tend to have a much lower prevalence $(4 \%)$ of stones than those seen before screening $(51 \%) .{ }^{1}$ Hypertension is a common associated feature of hyperparathyroidism ${ }^{156}$ but should present no problems with medical treatment. Since it may persist after parathyroidectomy ${ }^{6-8}$ and nonselective beta-blocking drugs such as propranolol may lower parathyroid hormone and serum calcium concentrations, ${ }^{9}$ raised blood pressure alone should not be an indication for parathyroidectomy. Caution is needed, however, in treating hypertension since thiazide diuretics may increase hypercalcaemia ${ }^{10}$ - and even a mild increase may progress to a hypercalcaemic crisis, ${ }^{11}$ though the risk of this severe complication may have been overestimated. ${ }^{3}$

Diffuse osteopenia, ${ }^{12}$ often associated with vertebral crush fractures, ${ }^{13} 14$ is now a more common manifestation of hyperparathyroid bone disease than is osteitis fibrosa ${ }^{14}{ }^{15}$; in patients identified by screening $20 \%$ show radiological evidence of bone disease $(12 \%$ osteoporosis, $8 \%$ hyperparathyroid bone disease). ${ }^{1}$ Even though there was an unexpectedly low prevalence of osteoporosis in this study the fact that, left untreated, mild asymptomatic hyperparathyroidism can lead to irreversible and symptomatic skeletal rarefraction must cause concern. Furthermore, in one study drawing attention to vertebral crush fractures as a feature of hyperparathyroidism ${ }^{13}$ half the patients had apparently mild disease with a serum calcium concentration below $2 \cdot 75 \mathrm{mmol} / 1$. Since osteoporosis and hyperparathyroidism are both found most commonly in postmenopausal women, we clearly need to find out whether the risk of developing osteoporosis is increased in the hyperparathyroid women by conservative management.

Emotional disorders (depression, psychosis, and severe neurosis) were found in $20 \%$ of patients in the Mayo Clinic study, ${ }^{1}$ but the symptoms of hyperparathyroidism must surely merge imperceptably into much non-specific illness. Although major psychiatric symptoms may respond to parathyroidectomy ${ }^{1617}$ we cannot necessarily extrapolate from patients showing symptoms at presentation to those identified by screening.
What degree of hyperparathyroidism, then, justifies intervention? The availability of medical facilities and a cultural assessment of what is "good" and what is "harmful"' are among the factors that must influence the decision. Extrapolation from the Mayo Clinic study suggested that curing the same degree of hyperparathyroidism throughout the United States would cost an astronomical $\$ 60-164 \mathrm{~m}$ annually. Perhaps our current financial plight will bolster our intuitive reservations about the advice that parathyroidectomy is best recommended for all patients because it is curative and avoids the anxiety and burden of intensive surveillance. ${ }^{18}$ That we need more information is undoubted, but if a prospective study showed parathyroidectomy to be unnecessary might not the same apply to intensive and therefore costly follow-up?

${ }^{1}$ Heath H, Hodgson SF, Kennedy MA. Primary hyperparathyroidism. Incidence, morbidity and potential economic impact in a community. $N$ Engl F Med 1980;302:189-93.

2 Evans JG, Rose G. Hypertension. Br Med Bull 1971;27:37-42.

3 Purnell DC, Scholz DA, Smith LH, et al. Treatment of primary hyperparathyroidism. Am $\mathcal{F}$ Med 1974;56:800-9.

${ }^{4}$ Purnell DC, Smith LH, Scholz DA, Elveback LR, Arnaud CD. Primary hyperparathyroidism: a prospective clinical study. Am f Med 1971; 50:670-8.

5 Earll JM, Kurtzman NA, Moser RH. Hypercalcemia and hypertension. Ann Intern Med 1966;64:378-81.

6 Watson L. Primary hyperparathyroidism. Clinical Endocrinology and Metabolism $1974 ; 3: 215-35$.

${ }^{7}$ Hellström J, Birke G, Edvall CA. Hypertension in hyperparathyroidism. Br $\mathcal{F}$ Urol 1958;30:13-24.

${ }^{8}$ Cope O. Hyperparathyroidism: diagnosis and management. Am $\mathcal{F}$ Surg $1960 ; 99: 394-403$

${ }^{9}$ Caro JF, Castro JH, Glennon JA. Effect of long-term propranolol administration on parathyroid hormone and calcium concentration in primary hyperparathyroidism. Ann Intern Med 1979;91:740-1.

${ }^{10}$ Christensson $T$, Hellström $K$, Wengle $B$. Hypercalcemia and primary hyperparathyroidism. Prevalence in patients receiving thiazides as detected in a health screen. Arch Intern Med 1977;137:1138-42.

11 Eisenberg E, Gotch FA. Normocalcemic hyperparathyroidism culminating in hypercalcemic crisis. Treatment with hemodialysis. Arch Intern Med 1968;122:258-64.

12 Pak CYC, Stewart A, Kaplan R, Bone H, Notz C, Browne R. Photon absorptiometric analysis of bone density in primary hyperparathyroidism. Lancet 1975 ;ii:7-8.

${ }^{13}$ Dauphine RT, Riggs BL, Scholz DA. Back pain and vertebral crush fractures: an unemphasized mode of presentation for primary hyperparathyroidism. Ann Intern Med 1975;83:365-7.

14 Genant HK, Heck LL, Lanzl LH, Rossmann K, Horst JV, Paloyan E. Primary hyperparathyroidism: a comprehensive study of clinical, biochemical and radiographic manifestations. Radiology 1973;109: 513-24.

${ }^{15}$ Aurbach GD, Mallette LE, Patten BM, Heath DA, Doppman JL, Bilezikian JP. Hyperparathyroidism: recent studies. Ann Intern Med $1973 ; 79: 566-81$.

${ }^{16}$ Karpati G, Frame B. Neuropsychiatric disorders in primary hyperparathyroidism. Arch Neurol 1964;10:387-97.

17 Gatewood JW, Organ CH, Mead BT. Mental changes associated with hyperparathyroidism. Am f Psychiatry 1975;132:129-32.

${ }^{18}$ Coe FL, Favus MJ. Does mild asymptomatic hyperparathyroidism require surgery ? $N$ Engl F Med 1980;302:224-5.

\section{Audit and improvement of performance: Is pathology a special case?}

Medical audit and its consequences have been discussed recently in a series of articles ${ }^{1}$ in the $B M Y$. The subject was also debated again at the BMA's Annual Representative Meeting last week ( $\mathrm{p} 240$ ), when a priority motion instructing Council "to stop surveying any imposed method of medical audit" (our italics) was passed by 173 votes to 153 . But clearly from the speeches at the ARM doctors are acutely aware of 